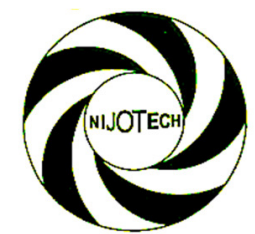

Nigerian Journal of Technology (NIJOTECH)

Vol. 34 No. 2, April 2015, pp. 223 - 231

Copyright(C) Faculty of Engineering,

University of Nigeria, Nsukka, ISSN: 111 15-8443

www.nijotech.com

http://dx.doi.org/10.4314/njt.v34i2.2

\title{
ASSESSMENT OF BAGASSE ASH EFFECT ON THE CALIFORNIA BEARING RATIO OF USED OIL CONTAMINATED LATERITIC SOILS
}

\author{
J. A. Sadeeq ${ }^{1,}$, J. Ochepo ${ }^{2}$ and A. B. Salahudeen ${ }^{3}$ \\ 1,2 Department of Civil EngineERING, AhMAdu Bello University, ZARIA, NIGERIA \\ ${ }^{3}$ Samaru College of Agriculture, Division of Agricultural Colleges, Ahmadu Bello Univ., Zaria, NigERIA \\ E-mail Addresses: ${ }^{1}$ muazbj@gmail.com, ${ }^{2}$ ochepo1@gmail.com, ${ }^{3}$ jasadeeq@yahoo.com
}

\begin{abstract}
This study was carried out to evaluate the effect of bagasse ash on the California bearing ratio of lateritic soil. Laboratory tests were performed on the natural and bagasse ash treated soil samples in accordance with BS 1377 (1990) and BS 1924 (1990) respectively. Treated specimens were prepared by mixing the soil with bagasse ash in steps of 0,2, 4, 6 and $8 \%$ by weight of dry soil and contaminating it with used oil in steps of 0, 2, 4, and $6 \%$ by weight of dry soil. The preliminary laboratory investigation carried out on the natural lateritic soil shows that it falls under Silt-Clay material of Group A-6 using AASHTO classification and inorganic clay material of low to medium plasticity CL according to Unified Soil Classification System (USCS). The specific gravity of the soil samples decreased from 2.61 for the natural soil to 2.48 at $8 \%$ bagasse ash content and to 2.16 and 2.11 at $6 \%$ oil / $0 \% B A$ and $6 \%$ oil / $8 \% B A$ contents respectively. The liquid and plastic limits increased from 36.32 and $21.30 \%$ respectively to peak values of 38.00 and $21.54 \%$ at $2 \%$ bagasse ash content for all oil contents. The maximum dry density (MDD) of the soil increased from $1.48 \mathrm{Mg} / \mathrm{m}^{3}$ for the natural soil to peak value of $1.49 \mathrm{Mg} / \mathrm{m}^{3}$ at $8 \%$ bagasse ash content for all oil contents. The Optimum Moisture Content (OMC) increased from a value of $18.5 \%$ for the natural soil to $19.0 \%$ at 2 and $4 \%$ bagasse ash contents and then after decreased. The unsoaked California bearing ratio values from $4 \% B A$ content and above met the minimum CBR value of $30 \%$ specified by (BS 1990) for materials suitable for use as base course material when determined at MDD and OMC. However, the highest CBR value of $62 \%$ recoded at $8 \% B A$ content failed to meet the $80 \%$ CBR value recommended by the Nigerian general specification (1997) for cement stabilization. Oil contamination resulted in reduced CBR values (strength) in lateritic soils.
\end{abstract}

Keywords: Bagasse ash, Used oil, Contamination, Lateritic soil, California bearing ratio

\section{INTRODUCTION}

Laterite is a clayey soil horizon rich in iron and aluminum oxides, formed by weathering of igneous rocks in moist warm climates, [1]. It is composed mainly of iron and aluminum compounds and poor in humus and essential plant nutrients such as phosphorus, nitrogen and potassium, but may contain large amount of quartz and kaoline [2]. Lateritic soils are the product of intensive weathering that occurs under tropical and subtropical climatic condition resulting in the accumulation of hydrated iron and aluminum oxides [2]; [3]. Lateritic soils as are soil groups rather than well-defined materials are most commonly found in the leached soils of the humid tropics where they were first studied. Lateritic soils are formed under weathering systems productive of the process of laterization [3].

The most important characterization is the decomposition of ferro-aluminium silicate minerals and the permanent deposition of sesquioxide (i.e., oxides of iron and Aluminum - $\mathrm{Fe}_{2} \mathrm{O}_{3}$ and $\mathrm{Al}_{2} \mathrm{O}_{3}$ ) within the profile to form the horizon of materials known as laterite [4]. The term "laterization" describes the processes that produce laterite soils [5]. Construction Industry Research and Information Association (CIRIA)[6], proposed the following definition for lateritic soils which states that "laterite in all its form is a highly weathered natural material formed by the concentration of the hydrated oxides of iron and aluminum, this concentration may be by

* Corresponding Author, Tel: +234-806-360-0851 
residual accumulation or by solution, movement and chemical precipitation" [7].

Lateritic soils have been used successfully for the construction of roads, highways, aircraft runways embankments and earth dams in various parts of the tropics. The degree of success in the use of these soils as a construction material is said to depend on their characteristics and the specific purpose for which they are being used. A number of geotechnical studies on both stabilized and unstabilised lateritic soils which are for specific application to road construction have been conducted [8 and 9].

Petroleum is a naturally occurring flammable liquid consisting of a complex mixture of hydrocarbons of various molecular weights and other liquid organic compounds that are found in geologic formations beneath the Earth's surface. The name Petroleum covers both the naturally occurring unprocessed crude oils and petroleum products that are made up of refined crude oil.

The Niger-Delta region of Nigeria today has been experiencing an unending problem of environmental degradation, especially due to oil spillage, pipeline vandalization (sabotaging and stealing), accidents and explosions, while some are due to poor maintenance by oil companies mostly due to unengineered waste disposal methods. Other sources of oil contamination in Nigeria are discharge from near-shore operations, urban and industrial effluents discharge, ballast water from oil tankers, accidental spills during loading and equipment failure at loading sites, [10]. Exploration activities have resulted to the release of large quantities of petroleum products into the environment and this has affected the soils in this region. These petroleum products released contaminate the soil, thus subjecting the soil to changes in its engineering properties, making it unsuitable to be used as material for road construction, capping layer for car parks, landfill cover material and detrimental to buildings and structures standing on it due to loss of bearing capacity, [11].

The Department of Petroleum Resources estimated 1.89 million barrels of petroleum were spilled into the Niger Delta between 1976 and 1996 out of a total of 2.4 million barrels produced. Most of these spills (69 $\%$ ) occurred off-shore, a quarter was in swamps and 6 $\%$ spilled on land. The Nigerian National Petroleum Corporation (NNPC) places the quantity of petroleum jettisoned into the environment yearly at 2,300 cubic meters with an average of 300 individual spills annually, [12].
In general, oil contaminated soil is any earthen material or artificial fill that has human or natural alteration to its physical, chemical, biological or radiological integrity resulting from introduction of crude oil product, any fraction or derivative thereof (such as gasoline, diesel oil or motor oil) or oil base product [13].

Oil contaminated soils pose a threat to human health and the environment if left unattended. These contaminated soils are not only a challenge for the environmentalists but also for the geotechnical engineers. Geotechnical Engineers are faced with increasing challenges and thus, it will be appropriate to carry out studies to develop methodologies for testing, identification, classification, stabilization, utilization and remediation techniques so as to eliminate or significantly reduce the risk oil contamination poses. Such studies could be aimed at converting it to road base material or topping layer for car parks and roads after mixing with aggregate or a stabilizing agent. In this case, bagasse ash is being investigated as a potential stabilizing agent, [11].

One of the most effective ways in terms of environmental benefits, product-type versatility and cost effectiveness in treating contaminated soils in order to make it suitable for engineering purposes such as the construction of road sub-grade (i.e. the natural foundation which receives load from pavement) is by using industrial wastes such as ricehusk ash, bagasse ash, cement kiln dust, etc. [14].

Sugarcane is one of the major crops grown in over 110 countries and its total production is over 150 million tons. After the extraction of the sugar juice from sugarcane, about $40-45 \%$ fibrous residue is left which is reused in the same industry as fuel in boilers for heat generation leaving behind $8-10 \%$ ash as waste. This ash is known as sugarcane bagasse ash (SCBA). Bagasse is the fibrous residue generated after the juice has been extracted from the sugar cane plant. It is normally deposited as waste and it litters the environment. Most of the bagasse produced, amounting to one-third of all the cane crushed in some cases supplies the fuel for the generation of steam which eventually results in bagasse ash. The resulting ash is deposited in stockpiles which are normally dumped in waste landfills and constitute environmental problems to the society. When bagasse is left in the open, it ferments and decays; this brings about the need for safe disposal of the pollutant, which when inhaled in large doses can result in respiratory disease known as bagassiosis [16]. 
According to Misari et al, [16] the estimated land under sugarcane cultivation in Nigeria is between 25,000 to 30,000 hectares. However there is a potential for land under sugarcane cultivation to be expanded to 147,000 hectares. Also sugarcane yield in Nigeria was estimated at 80 tonnes per hectare, which puts the amount of sugarcane produced today at between 2 to 2.4 million tones. According to [17] the estimated average amount of bagasse from sugarcane is $30 \%$ and the ash content from bagasse is $2.48 \%$, which leaves the amount of bagasse produced in Nigeria annually to lie between 600,000 tonnes and 720,000 tonnes while the amount of bagasse ash lies between 14,880 tonnes and 17,856 tonnes. Some of this bagasse is burnt to generate steam at the factories for the production processes. But this still leaves the problem of disposing the bagasse ash.

Bagasse is also used to make disposable food containers, replacing materials such as Styrofoam which are increasingly regarded as environmentally unacceptable. It can also be used in a variety of applications such as flame retardants, insecticide and bio-fertilizer, insulator and ceramic glaze, [18]. It has also been shown to be suitable in geo-environmental application for treatment of lateritic soils in construction of compacted clay liners for landfills, [19]. [20] recommended after testing the effects of bagasse ash and curing period on the permeability of laterite compacted using standard proctor energy that materials of this kind can be used for low cost roads with light traffics. However, results of various studies conducted on the properties of bagasse ash shows that the ash possesses some pozzolanic properties [15].

There is a growing demand for fine amorphous silica materials in the construction industry today, hence it is economical for industrial waste materials such as bagasse to be recycled and reconverted into useful materials which can be used as additives to improve the engineering properties of deficient soils and making it suitable as a construction material. A study on the attenuative capacity of compacted black cotton soil treated with bagasse ash showed that pollutants represented by calcium, magnesium, potassium and sodium can be effectively attenuated by using black cotton soil-bagasse ash mixtures containing an optimum of $8 \%$ bagasse ash by weight of dry soil [21]. The California Bearing Ratio (CBR) test is a simple strength test that compares the bearing capacity of a material with that of a well-graded crushed stone (a high quality crushed stone material has a CBR at $100 \%)$. It is primarily intended for, but not limited to, evaluating the strength of cohesive materials having maximum particle sizes less than $19 \mathrm{~mm}$ (0.75 in.) [22]. It was developed by the California Division of Highways around 1930 and was subsequently adopted by many countries. The evaluation of CBR values for lateritic soils has shown that the stability characteristics of lateritic soils may be reliably improved for highway and airfield construction. It is also one of the common tests used to evaluate the strength and stability of a soil [14].

\section{MATERIALS AND METHODS}

\subsection{Materials}

The materials used in this study are described below.

\subsubsection{Soil}

The soil used in this study is a natural reddish brown laterite which was collected from a borrow pit in Shika village, Zaria Local Government Area, Kaduna State in Northern part of Nigeria, (latitude $11^{\circ} 15^{\prime} \mathrm{N}$ and longitude $7045^{\prime} \mathrm{E}$ ), by using the method of disturbed sampling at $1.0 \mathrm{~m}$ depth from the natural earth surface to avoid organic matter influence.

\subsubsection{Bagasse ash}

The Bagasse was obtained locally from a sugarcane processing plant situated in Gaskiya, Zaria local government area in Kaduna State. The sugarcane waste (Bagasse) was collected, air-dried and burnt under atmospheric conditions. The residue obtained after burning was the ash that was collected in sacks and transported to the soil laboratory of the department of civil engineering, Ahmadu Bello University, Zaria. The ash was then passed through B.S. sieve No. $200(0.075 \mathrm{~mm})$ to meet the requirements of ASTM (618-78). The specific gravity of the Bagasse ash (BA) is 2.34. The chemical composition of the Bagasse ash (BA) was determined at the Center for Energy Research and Training (CERT), A. B. U. Zaria using the method of Energy Dispersive X-Ray Fluorescence.

\subsubsection{Used oil}

The used oil was collected from Oando lubrication workshop adjacent Ahmadu Bello University main gate, Samaru Campus, Zaria Kaduna state. It is used motor oil, black in colour with petrol and engine oil chocking smells and feels greasy on the palm. 


\subsection{Methods}

\subsubsection{Index properties}

Laboratory tests were performed to determine the index properties of the natural soil and bagasse ash treated lateritic soil in accordance with BS 1377 [23] and BS 1924 [24], respectively.

\subsubsection{Compaction}

The compaction tests were performed on the natural soil and the bagasse ash treated soils ( at 0, 2, 4, 6 and $8 \%$ BA treatment by dry weight of soil.); using the British Standard light (BSL) energy.

\subsubsection{California bearing ratio test}

The strength characteristic test performed in this study is the California bearing ratio (CBR) test. It was carried out in accordance with the Nigerian General Specification [25] which specified that specimen be cured in the dry for six days and then soaked for 24 hours before testing.

\subsubsection{Soil contamination}

The lateritic soil used in this research was thoroughly mixed after been contaminated with used engine oil using $0,2,4$ and 6 percentages by dry weight of each soil sample in order to simulate the ideal field conditions. Wherever applicable, the oil contamination was done after thorough mixing with bagasse ash.

\section{RESULTS AND DISCUSSION}

\subsection{Properties of Materials}

The index properties of the natural soil show that it is an A-6 soil according to AASHTO classification system and low plasticity clay (CL), using the Unified Soil Classification System, USCS [26]. The soil has a liquid limit value of $36.32 \%$, plastic limit of $21.30 \%$, plasticity index of $15.02 \%$, linear shrinkage of $3.60 \%$ and specific gravity of 2.61 with $70.85 \%$ of the soil particles passing the BS No. 200 sieve $(0.075 \mathrm{~mm}$ aperture). The predominant clay mineral is kaolinite. The properties of the natural soil are summarized in Table 1, while its particle size distribution curve is shown in Figure 1. The properties of the used oil are given in Table 2 while the oxide compositions of the bagasse ash are summarized in table 3 .
Table 1: Properties of the Natural Lateritic Soil

\begin{tabular}{lc}
\hline Properties & Quantity \\
\hline Percentage passing BS sieve no. 200 & 70.85 \\
Liquid limit (LL) (\%) & 36.32 \\
Plastic limit (PL) (\%) & 21.30 \\
Plasticity index (PI) (\%) & 15.02 \\
Linear shrinkage (LS) (\%) & 3.60 \\
AASHTO classification & $\mathrm{A}-6$ \\
USCS & $\mathrm{CL}$ \\
Group index & 107.74 \\
Specific gravity & 2.61 \\
Natural moisture content (\%) & 15.8 \\
Colour & Reddish brown \\
Optimum moisture content (OMC) (\%) & 18.50 \\
Maximum dry density (MDD) (kg/m $\left.{ }^{3}\right)$ & 1.48 \\
Dominant clay mineral & Kaolinite \\
\hline
\end{tabular}

Table 2: Properties of the Used Oil

\begin{tabular}{lc}
\hline Characteristics & Quantity \\
\hline Specific gravity & 0.70 \\
Flash point $(\stackrel{\circ}{\circ})$ & 168 \\
Fire point $(\stackrel{\circ}{\circ})$ & 220 \\
Viscosity $(\mathrm{cP})$ & 1.17 \\
Density $\left(\mathrm{g} / \mathrm{cm}^{3}\right)$ & 0.76 \\
\hline
\end{tabular}

Table 2: Oxide composition of Bagasse ash

\begin{tabular}{lc}
\hline Oxide & Composition \\
\hline $\mathrm{SiO}_{2}$ & 57.95 \\
$\mathrm{Al}_{2} \mathrm{O}_{3}$ & 8.23 \\
$\mathrm{FeO}_{3}$ & 3.96 \\
$\mathrm{CaO}$ & 4.52 \\
$\mathrm{MgO}$ & 4.47 \\
$\mathrm{~K}_{2} \mathrm{O}$ & 2.41 \\
$\mathrm{LOI}^{*}$ & 5.0
\end{tabular}

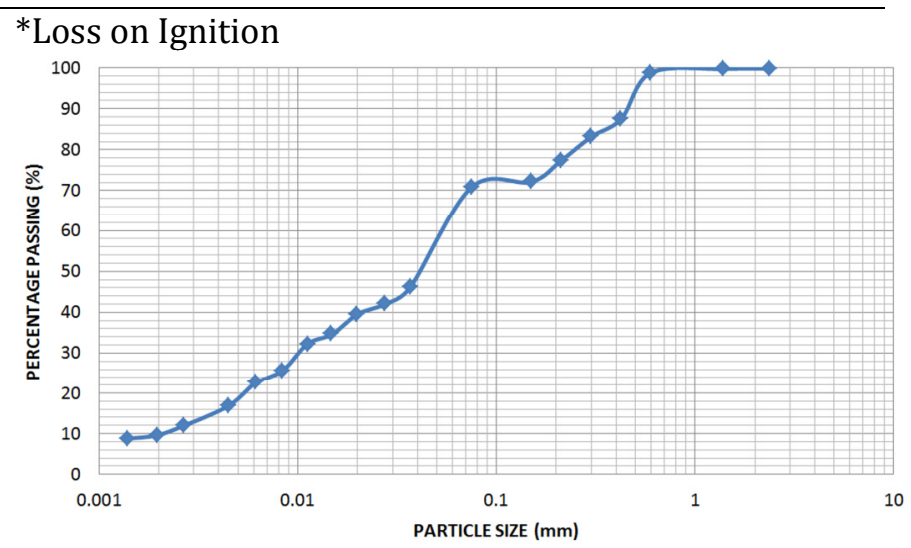

Figure 1: Particle size distribution curve for the natural lateritic soil

\subsection{Effect of Bagasse ash on the Specific Gravity of Used Oil Contaminated Lateritic Soil}

The specific gravity of solid particles is the ratio of the mass of a given volume of solids to the mass of an equal volume of water. Specific gravity an important parameter used for the determination of the void ratio and particle size of any soil particle [27]. 


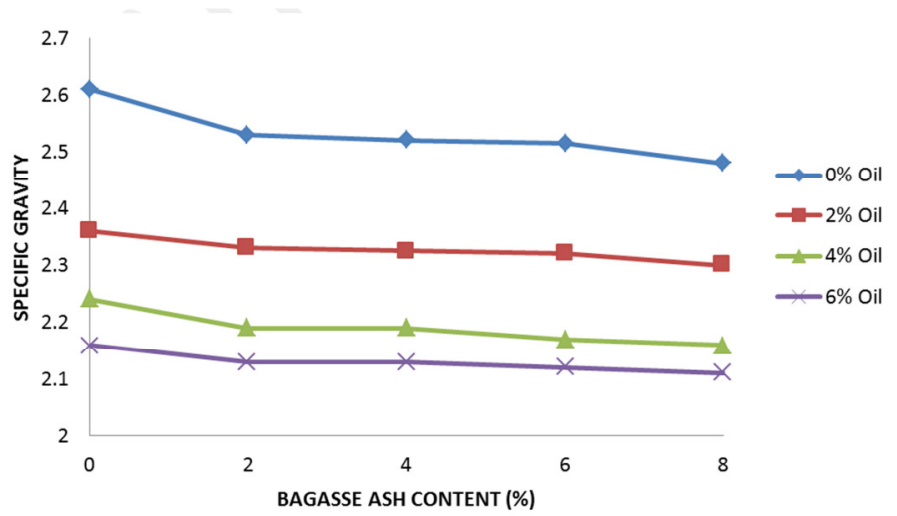

Figure 2: Variation of specific gravity of oil contaminated soil with bagasse ash content

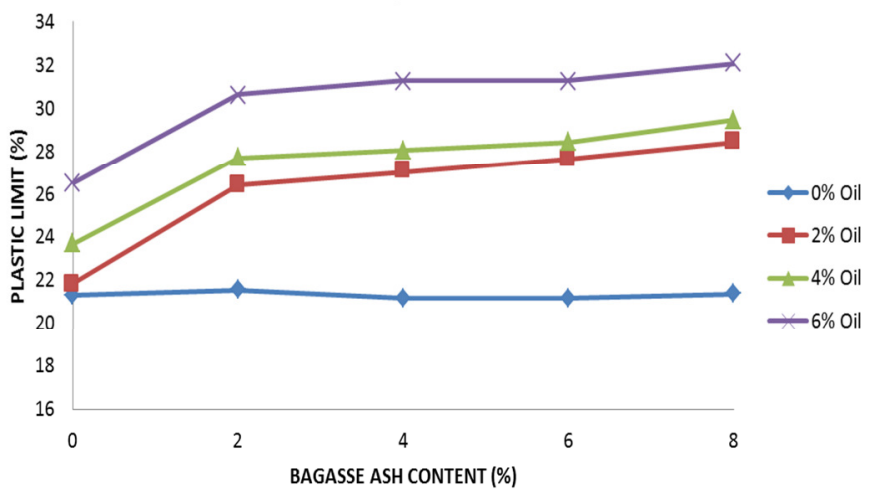

Figure 4: Variation of plastic limit of oil contaminated soil with bagasse ash content

The value of the specific gravity of the oil contaminated soil-bagasse ash mixes decreased steadily from a value of 2.61 for the untreated lateritic soil to 2.11 at $8 \% \mathrm{BA} / 6 \%$ Oil contents. The specific gravity decreased with increase in both oil and BA contents. This decrease in specific gravity is due to the lower specific gravity values of both bagasse ash (2.34) and used oil (0.70) compared to that of the natural soil.

\subsection{Effect of Bagasse ash on Atterberg Limits of Oil Contaminated Lateritic Soil}

The variations of Atterberg limits of oil contaminated lateritic soil mixed with bagasse ash content are shown in Figures 3 to 6. The liquid and plastic limits of the lateritic soil increased with increasing addition of used oil. This increase in liquid limit is an indication of increasing value of compression index and higher proneness of the soil towards settlement [28]. An increase in plastic limit (PL) was also observed as oil content increased. This may be due to the lubricating effect of oil making the particles to roll over one another hence the increased plastic behaviour. The plasticity index (PI) decreased with increase in oil content while the linear shrinkage (LS) increased then

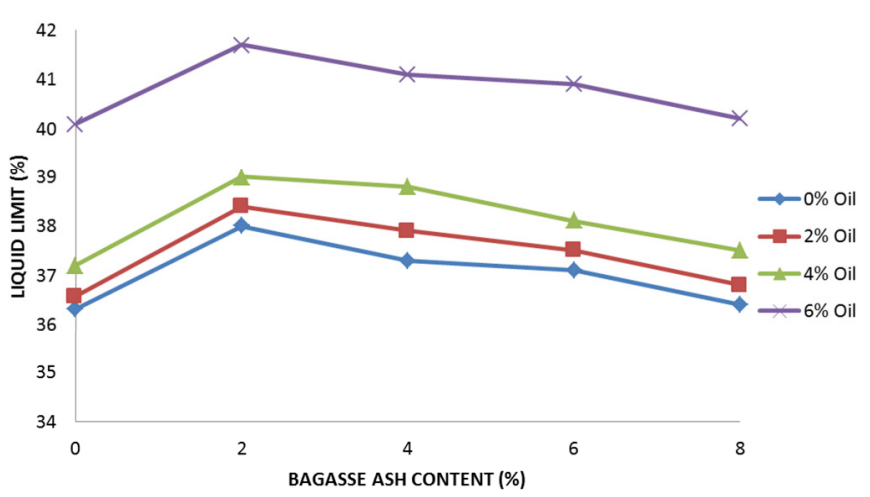

Figure 3: Variation of liquid limit of oil contaminated soil with bagasse ash content

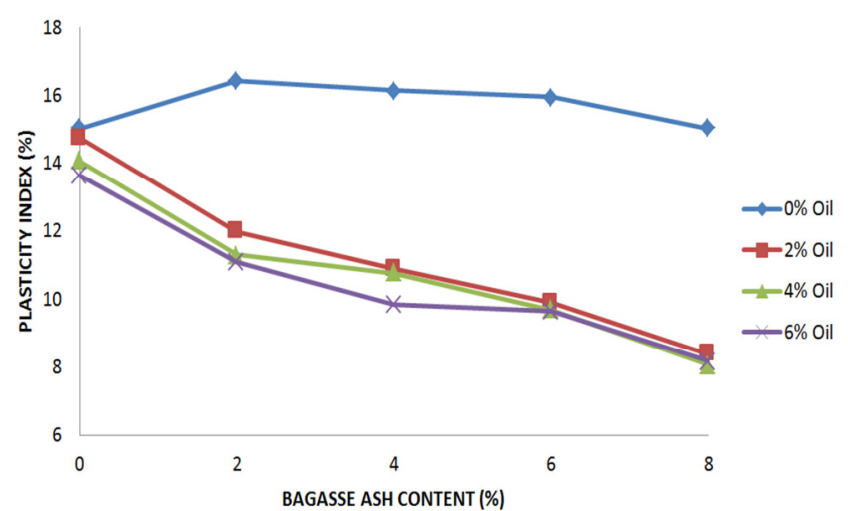

Figure 5: Variation of plasticity index of oil contaminated soil with bagasse ash content

decreased. The introduction of bagasse ash into the oil contaminated soil first caused an increase in the Liquid limits up to a peak value at $2 \%$ bagasse ash treatment and thereafter decreased. The increase can be attributed to addition of bagasse ash which introduced more pozzolanic substance into the specimen that required more water for hydration to be completed. The subsequent decrease can be associated with the agglomeration and flocculation of the clay particles which is as a result of exchange ions at the surface of the clay particles.

This observed trend is in agreement with Ramzi et al. [29]. Venkaramuthyalu et al. [30], Suhail et al.[31] and Ramzi et al. [32] reported that the reduction in plasticity index with chemical treatment could be attributed to the depressed double layer thickness due to cation exchange by potassium, calcium and ferric ions.

\subsection{Compaction Characteristics}

The variations of maximum dry density (MDD) and optimum moisture content (OMC) of used oil contaminated lateritic soil with bagasse ash content are shown in figures 7 and 8. The MDD steadily increased with increase in both oil and BA contents. 


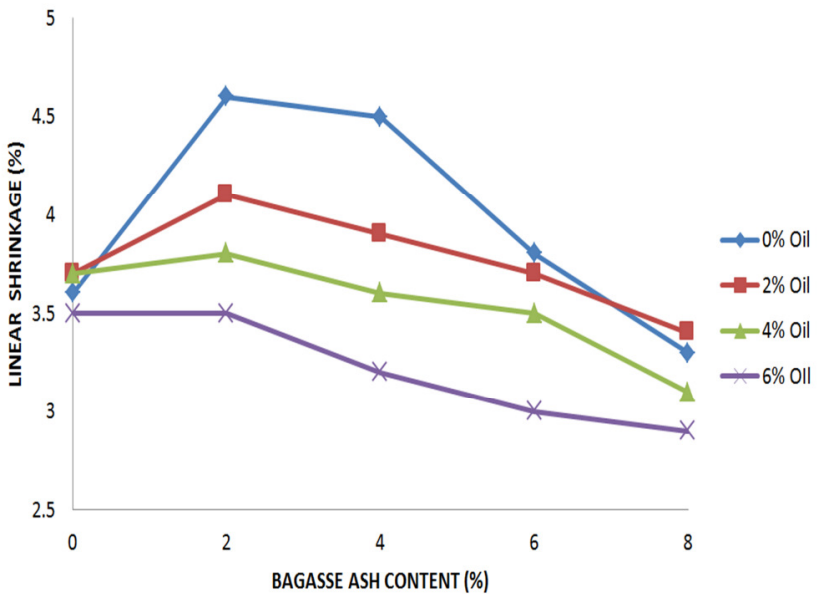

Figure 6: Variation of linear shrinkage of oil 20 contaminated soil with bagasse ash content

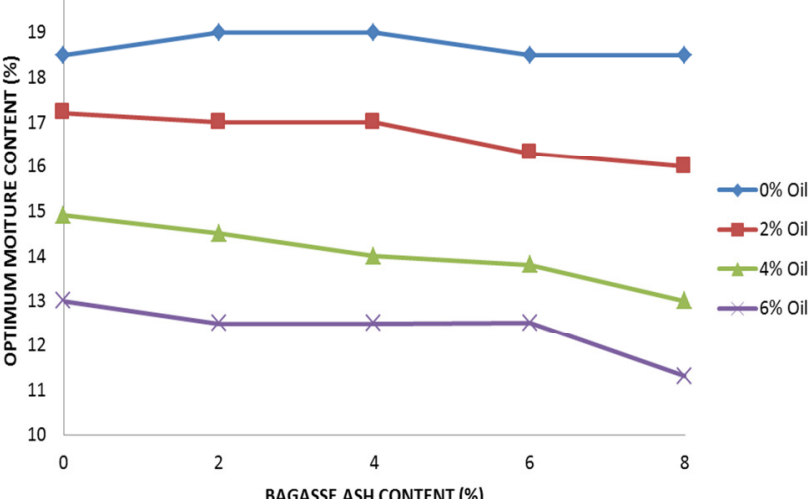

Figure 8: Variation of optimum moisture content of oil contaminated soil with bagasse ash content

The continuous increase in MDD was attributed to the lubricating effect due to the presence of oil which facilitates compaction and reduced the amount of water needed to reach maximum density. This increase in dry density with addition of oil may also be due to cation exchange reactions and it could also be due to oil being a fluid occupying the voids within the soil matrix [32 and 33]. The decrease in OMC as oil content increases may be due to the fact that oil being a fluid with lubricating characteristics tends to facilitate slippery of the soil particles relative to each other which resulted in reaching higher densities at lower moisture content. The trend observed in MDD and OMC is in agreement with findings of Lees et al [34]; Ola [35]; Meegoda et al., [28]; Iorliam et al. [36]; Ochepo and Salahudeen [37].

The OMC decreased continuosely with increased used oil content, but with respect to BA content, it increased to a peak value at 2 and $4 \%$ BA contents and thereafter decreased. This trend is in conformity with results reported by Ola[38], Gidigasu [39] and Osinubi [40]. An explanation given to this trend was

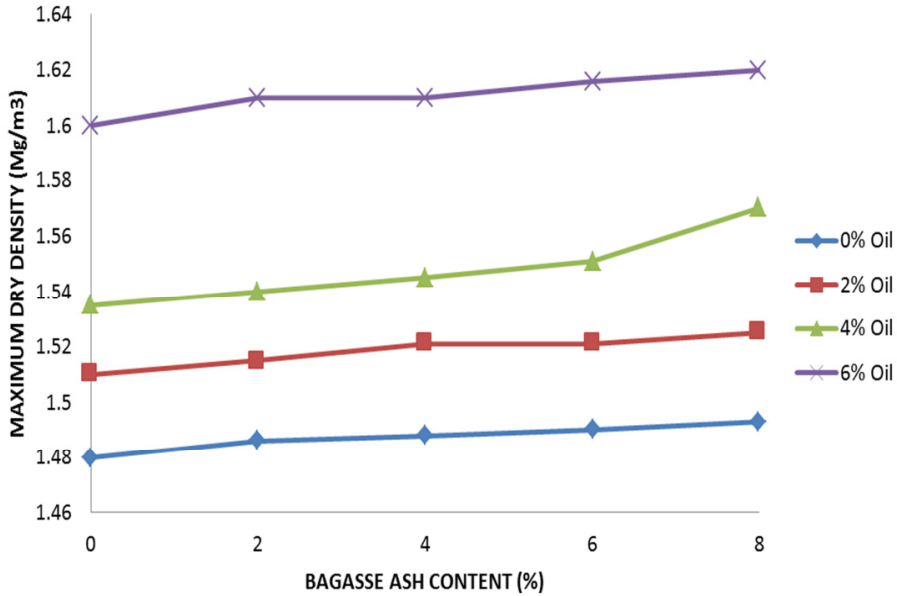

Figure 7: Variation of maximum dry density of oil contaminated soil with bagasse ash content

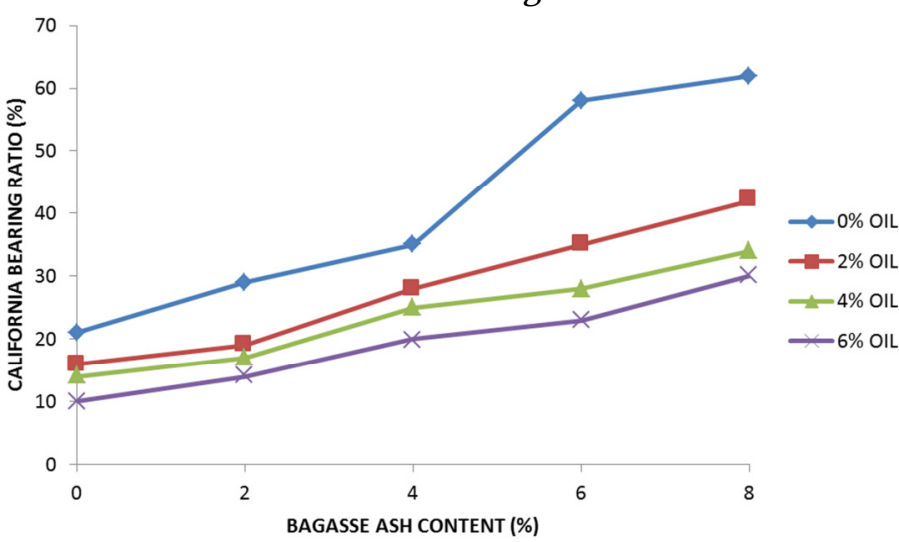

Figure 9: Variation of Unsoaked California Bearing Ratio of oil contaminated soil with bagasse ash content

that the increased demand for water commensurate with the higher amount of admixture required for its hydration reaction and dissociation needed for cation exchange reaction. The subsequent decrease in OMC with increase in BA content might be due to cation exchange reaction that caused the flocculation of clay fractions of the soil.

\subsection{California Bearing Ratio}

\subsubsection{Unsoaked CBR}

The variation of the unsoaked CBR values of used oil contaminated lateritic soil with bagasse ash content are shown in figures 9. A general increase in CBR values with BA content was observed. This increase could be due to the presence of adequate amounts of calcium required for the formation of calcium silicate hydrate $(\mathrm{CSH})$ and calcium aluminate hydrate $(\mathrm{CAH})$, which are the major compounds responsible for strength gain [41]. The soil -BA mixtures right from 4 \%BA content and above met the minimum CBR value of 30\% specified by (BS 1990) for materials suitable for use as base course material when determined at 
MDD and OMC. All the CBR values with the exemption of the value at $2 \%$ BA content at all percentage oil contamination agreed with the findings of Gidigasu and Dogbey [5], which stated that minimum CBR value of $20-30 \%$ is required for sub-bases when compacted at OMC. The CBR value however decreased with increase in oil content. This decrease may be due to the liquid oil that softened the soil mixes resulting in reduced strength. The reduction in strength of the used oil contaminated soil may be due to the penetration of the liquid oil in the soil fabrics and possible reactions between the hydrocarbon compounds in the oil with the calcium silicate gel. This may have disrupted the stability of the gel resulting in a material with a lesser strength [37]. However, the highest CBR value of $62 \%$ recoded at $8 \%$ BA content failed to meet the $80 \%$ CBR value recommended by the Nigerian general specification [25] for cement stabilization.

\subsubsection{Soaked CBR}

The variations of soaked CBR (24 hours soaking) of natural and BA-treated soil using is shown in Figure 10. The trend observed in the in the soaked CBR follow suit with that of unsoaked CBR as discussed in section 3.5.1. With the exemption of the CBR value at $8 \% \mathrm{BA}$ content with $0 \%$ oil contamination, none of the CBR values met the findings of Gidigasu and Dogbey [5], which stated that minimum CBR value of $20-30 \%$ is required for sub-bases when compacted at OMC. The continuous reduction in strength with increased percentage oil contamination rendered the contaminated soil detrimental for use in construction works since it means that when the soil is subjecting to a contaminated environment for a long period of time, the strength will deteriorate further.

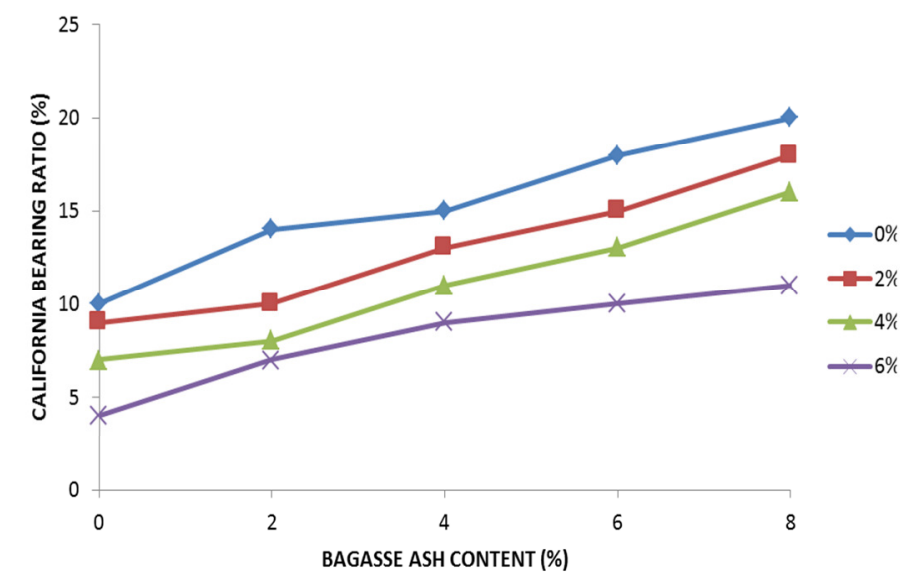

Figure 10: Variation of Soaked California Bearing Ratio of oil contaminated soil with bagasse ash content

\section{CONCLUSION}

From the results of tests conducted on the used oil contaminated lateritic soil treated with bagasse ash, the following conclusions could be drawn:

I. The lateritic soil used in this study is an A-6 soil using the AASHTO classification system and CL using the Unified Soil Classification System (USCS).

II. The properties of the natural soil improved with used oil contamination and bagasse ash treatment. The plasticity index decreased from $15.02 \%$ for the natural soil to $13.62 \%$ when contaminated with $6 \%$ oil content. This value is very close to the $12 \%$ plasticity index specified by clause 6201 of the Nigerian General Specifications (1997) for subbase type 1 materials. However, the $8.16 \%$ plasticity index value obtained at $6 \%$ oil/8 $\%$ bagasse ash content met the $12 \%$ plasticity index requirement by the Nigerian General Specifications (1997) for subbase type 1 materials. The specific gravity decreased steadily with increase in both oil and BA contents which indicates decrease in voids and hence higher densities.

III. The maximum dry density of the soil increased with increase in both oil and BA contents.

IV. The CBR values of soil samples treated with bagasse ash increased but reduced with used oil contamination. The unsoaked CBR values of soil BA mixtures right from $4 \% \mathrm{BA}$ content and above met the minimum CBR value of $30 \%$ specified by (BS 1990) for materials suitable for use as base course material when determined at MDD and OMC.

V. Oil contamination resulted in reduced strength in lateritic soils and therefore, contaminated soils should be avoided in use as construction materials.

5. REFERENCES[1] Agbenla, A. O. (2010) "Comparism of Engineering Properties of Oven Dried, Air Dried and Sun Dried Laterite" Department of Civil Engineering, University of Agriculture, Abeoukuta, Ogun State, Nigeria.

[2] Alexander, L. T. and Cady, J. G. (1962). "Genesis and Hardening of Laterite Soils" U. S Department of Agric. Technical Bulletin 1282, pp. 90.

[3] Gidigasu M.D. (1972) "Mode of Formation and Geotechnical Characteristics of Laterite Materials 
of Ghana in Relation to Soil Forming Factors". Eng. Geol. Vol 6: pp 79150.

[4] Ijimdiya, T.S. and Igboro, T. (2012) "The Compressibility Behavior of Oil ContaminatedSoils" Electronic Journal of Geotechnical Engineering, volume 17, bundle Y. pp 3653-3662.

[5] Gidigasu, M.D. and Dogbey, J.L.K. (1980)."Geotechnical characterization of laterized decomposed rocks for pavement construction in dry sub-humid environment". 6th South East Asian Conf. on Soil Engineering, Taipei, 1, 493506.

[6] Construction Industry Research and Information Association (CIRIA) (1988). "Laterite in Road Pavements." Special publication 47, Transportation Road Research Laboratory, London.

[7] Ijimdiya, T. S. (2013). "The Effects of Oil Contamination on the Consolidation Properties of Lateritic Soil" Development and Applications of Oceanic Engineering (DAOE) Volume 2 Issue, pp 53-59.

[8] Osinubi, K. J. (1998) a. "Influence of Compactive Delay on Properties of Cement Stabilized Lateritic Soil." Journal of Engineering Research 6(1); pp1326.

[9] Osinubi, K.J. and Katte, V.Y. (1997). Effect of elapsed time after mixing on grain size and plasticity characteristics I: Soil- Cement mixes. NSE Technical Transaction, Vol. 32, No. 4, pp. 6577.

[10] Nenibarini, Z. (2009) "Pollution And Poverty In The Niger Delta Region - What Is The Responsibility Of Oil Companies In Nigeria?" Paper presented at the University of Stavanger Conference, Stavanger, Norway.

[11] Al-Sanad, H.A., Shagoor, F.M., Hencher, S.R. and Lumsden, A.C. (1990). The influence of changing groundwater levels on the geotechnical behaviour of desert sands. Quarterly Journal Engineering Geology, 23, 357-364.

[12] Bronwen, M. (1999) "The Price of Oil Human Rights Watch". Retrieved November 9, 2007 from http://en.wikipedia.org/wiki/Human Rights Wat ch.

[13] Colorado Hazardous Waste Act (CHWA) (2002) "Title 25 Health: Environmental Control." Article 15 Hazardous Waste Part 1 - 5.

[14] Godwin, J. (2009) "The California Bearing Ratio of Used Oil Contaminated SoilTreated with Rice
Husk Ash" Unpublished work of the Department of Civil Engineering, Ahmadu Bello University, Zaria.

[15] Ajay, G., Anwar, A. M., Hatt O. K. and Ogat, A. H. (2007) "Properties of Sugarcane Bagasse Ash and its Potential as Cement- pozzolana Binder."

[16] Misari, S. M., Busari, I. O. and Gbiore, S. (1998). Current Status of Sugar Cane Research and Development in Nigeria. "Proceedings of The Inaugural Meeting and Planning Workshop for Collaborations of National Co-Ordinated Research Program on Sugar Cane (NCRPSC). pp. 2-12.

[17] Ogbonyomi, T. D. (1998). Possible Uses of Bagasse Ash as an Alternative Cement. Unpublished M.Sc Thesis, Ahmadu Bello University, Zaria, Nigeria.

[18] Niir Project Consultancy Services (NCPS) (October 2012) "Handbook on Agro Based Industries (2 ${ }^{\text {nd }}$ Revised Edition)".

[19] Eberemu, A. O. (2008) "Evaluation of Compacted Lateritic Soil Treated with Bagasse Ash as Hydraulic Barriers in Municipal Solid Waste Containment Systems." Unpublished Ph.D. dissertation, Department of Civil Engineering, Ahmadu Bello University, Zaria.

[20] Ogbe, A. (2006) "Effects of Bagasse Ash and Curing Period on the Permeability of Lateritic Soil Compacted using Standard Proctor Energy" Unpublished work of the Department of civil Engineering, Ahmadu Bello University, Zaria.

[21] Ijimdiya, T.S., and Osinubi, K.J.(2011) "Attenuative capacity of compacted black cotton soil treated with bagasse ash," Electronic Journal of Geotechnical Engineering, Vol 16, Bund. D, pp 419- 429.

[22] American Association of State Highway and Transportation Officials (AASHTO), (1986) Washington, D. C.. "Standard Specifications for Transportation Materials and Methods of Sampling and Testing, Twentieth Edition".

[23] British Standard (BS) 1377 (1990) "Methods of Test for Soils for Civil Engineering Purposes". British Standards Institute, London.

[24] British Standard (BS) 1924 (1990). Methods of Tests for Stabilized Soils. British Standards Institute, London.

[25] Nigerian General Specification (1997): Road Works and Bridges, Federal Ministry of Works and Housing, Abuja, Nigeria. 
[26] ASTM C618-93 specification (1992) "Fly Ash and Raw or Calcined Natural Pozzolan for use as Mineral Admixture in Portland Cement Concrete".

[27] Arora K. R. (2011) "Soil mechanics and foundation engineering" $7^{\text {th }}$ edition, p. 19.

[28] Meegoda, N.J., Chen, B., Gunasekara, S.D. and Pederson, P. (1998). "Compaction Characteristics of Contaminated Soils - Reuse as a Road Base Material" Recycled Materials in Geotechnical Applications, GSP 79, ASCE, pp 195-209.

[29] Ramzi, T., Amer, A., Ali, A. and Hilia A. (2001). "Use Of Cement Kiln Dust In Soil Stabilization". EJUQ. Vol.14 pp.61-76.

[30] Venkaramuthyalu, P., Ramu, K., and Prasada, R.G.V.R. (2012). "Study on performance of chemically stabilized expansive soil'. IJAET, Vol. 2, Issue 1, pp 139-148.

[31] Suhail, A.A.A., Khawla, A.K.A. and Ibrahaim, M.A.A. (2008). "Strength Durability And Hydraulic Properties Of Clayey Soil Stabilized With Lime And Industrial Waste Lime". Al-Rafidain Engineering. Vol. 16. No. 1. Pp.102-116.

[32] Osinubi, K. J. (2000). "Laboratory trial of soil stabilization of Nigerian black cotton soils" Nigerian Society of Engineers Technical Transactions, Vol. 35, No 4 pp 13 - 21.

[33] Oriola, F., and Moses, G. (2010). "Groundnut Shell Ash Stabilization of Black Cotton Soil”. Electron Journal of Geotechnical Engineering, Vol. 15, pp. 415-428.

[34] Lees, G., Abdelkader, M. O. and Hamdani, S. K. (1982). "Sodium chloride as additive in lime- soil stabilization" Journal Institute of Highway Engineers., 29, Vo; No(11), pp.8-16.

[35] Ola, S. A. (1991). "Laboratory testing and geotechnical characterization of black cotton soil and expansive shales in Nigeria", Proceedings $9^{\text {th }}$ Regional Conference for Africa on Soil Mechanics and Foundation Engineering, Balkema, Rotterdam, 991 - 995.

[36] Iorliam, A.Y., Agbede,I.O. and Joel, M. (2012). "Effect Of Cement Kiln Dust On Some Geotechnical Properties Of Black Cotton Soil'. EJGE. Vol. 17. pp.967-976.

[37] Ochepo, J. and Salahudeen, A. B. (2013). "Effect of oil contamination on lime and cement stabilized soil for pavement structures". 2013 Conference proceedings, Nigerian Institution of Civil Engineers, pp 43 - 53.

[38] Ola, S. A. (1978) "The geology and geotechnical properties of the black cotton soils of North Eastern Nigeria." Engineering Geology, Vol. 12, pp. 375-391.

[39] Gidigasu, M.D. (1976). Laterite Soil Engineering: Pedogenesis and Engineering Principles. Elsevier, Amsterdam, the Netherlands.

[40] Osinubi, K. J. (1999). "Evaluation of admixture stabilization of Nigerian black cotton soil." Nigerian Society of Engineers Technical Transactions, Vol. 34, No 3, pp 88-96

[41] Salahudeen, A. B. and Akiije, I. (2014). Stabilization of highway expansive soils with high loss on ignition content kiln dust. Nigerian Journal of Technology,. Vol. 33. No. 2, pp. 141 - 148. 